\title{
Management of acute diarrhea in children by community pharmacists in Lagos, Nigeria
}

Patricia U. OGBO, Bolajoko A. AINA, Roseline I. ADEREMI-WILLIAMS. Received (first version): $18-$ Oct-2013 Accepted: 23-Feb-2014

\begin{abstract}
${ }^{*}$
Background: Acute diarrhea in children leads to dehydration and death if not appropriately managed. World Health Organization (WHO) recommends treating diarrhea with oral rehydration therapy (ORT), fluids and foods. Proper management is hinged on accurate assessment of patients to identify the acute watery diarrhea.

Objective: To compare the knowledge and attitude of community pharmacists in the management of acute diarrhea in children with their observed practice. Methods: This study was carried out using two instruments: structured self-administered questionnaire to assess knowledge and attitude of community pharmacists in the management of acute diarrhea in children and simulated patient visits to evaluate assessment of patients, recommendation of products and instructions on feeding and fluid intake. The simulated patient visits were done in 186 pharmacies in the city of Lagos, Nigeria. Results: The study reveals that the knowledge and attitude of community pharmacists in the management of acute diarrhea in children was different from their observed practice. The difference was statistically significant $(p<0.05)$. During the simulations, $23 \%$ carried out appropriate assessment before recommending any products, and $15 \%$ recommended ORT alone. Although information to the pharmacists indicated non-dysentery, non-cholera, acute watery diarrhea, antibiotics and antidiarrheals were irrationally recommended and these were the mainstay of symptoms' management in practice. Questionnaire data revealed that $24 \%$ of pharmacists knew the correct instructions to give on food and fluid intake during diarrhea, whereas $8 \%$ followed $\mathrm{WHO}$ guideline on food and fluid intake during the visits. Conclusions: Assessment of patients to determine acute diarrhea was inadequate. Observed practice in managing acute diarrhea in children was inappropriate and significantly different from their claims in the questionnaire. The recommendation of ORT was scanty and advice on food and fluid intake was inadequate and sometimes inappropriate. This study shows that only $15 \%$ of community pharmacists managed acute diarrhea in children according to the $\mathrm{WHO}$ guidelines.
\end{abstract}

Keywords: Diarrhea; Community Pharmacy Services; Professional Practice; Guideline Adherence; Patient Simulation; Nigeria

\footnotetext{
*Patricia Uche OGBO. B. Pharm, MSc. Lecturer II. Department of Clinical Pharmacy and Biopharmacy, Faculty of Pharmacy, University of Lagos. Lagos (Nigeria). ucogbo@yahoo.com

Bolajoko Ajoke AINA. B. Pharm, MSc, PhD. Associate Professor. Department of Clinical Pharmacy and Biopharmacy, Faculty of Pharmacy, University of Lagos. Lagos (Nigeria). bolajokoaina@yahoo.com Roseline Iberi ADEREMI-WILLIAMS. B. Pharm, M. Pharm, PhD. Lecturer I. Department of Clinical Pharmacy and Biopharmacy, Faculty of Pharmacy, University of Lagos. Lagos (Nigeria). iberose31@yahoo.com
}

\section{INTRODUCTION}

Global deaths from diarrhea of children aged less than five years have been estimated at 1.87 million. Seventy-eight per cent of these occur in the developing world. ${ }^{1-3}$ Diarrheal diseases have been classified into four clinical types: Acute watery diarrhea, acute bloody diarrhea (dysentery), persistent diarrhea and diarrhea with severe Malnutrition. ${ }^{4}$ Acute watery diarrhea is of sudden onset and lasts for several hours or days. The main concern is dehydration. Weight loss can occur if feeding is being withheld. Acute bloody diarrhea is considered when blood and mucous are present in the stool. Persistent diarrhea lasts for 14 days or longer. Diarrhea with severe dehydration requires special attention to exclude severe systemic infection, dehydration, severe electrolyte imbalance, heart failure and vitamin and mineral deficiencies. ${ }^{3}$ Despite the wide range of organisms associated with gastrointestinal infections, the mainstay of the treatment of a person with acute watery diarrhea is appropriate fluid and electrolyte therapy and nutritional management. ${ }^{1}$

During the first two years of life each young child experiences an average of three to four episodes per year which result in estimated 4-5 million diarrhea-associated deaths annually in the world., However, a simple and inexpensive treatment can prevent death and treat acute watery diarrhea. World Health Organization insists on treating with ORT, fluids and foods., ${ }^{1,3,4}$ Foods and fluids including milk and breast milk should not be withdrawn from a child who has diarrhea. However only $39 \%$ of children with diarrhea in developing countries receive oral rehydration therapy and continued feeding. ${ }^{6}$

Despite the success of the World Health Organization programs, many clinicians, pharmacists and other health care providers in industrialized and developing countries have been reluctant to use ORT.

A review group on the treatment practices of diarrhea in children in the United States of America noted that although ORT is a well-established therapy for the treatment and prevention of dehydration due to diarrhea, and has saved millions of lives around the world, it was still grossly underused.

The pharmacy is a health resource and the pharmacist an indispensable health care professional who is easily accessible in the 
community. The community pharmacist is in a unique position to give advice and provide therapy for the prevention and treatment of diarrhea and the associated problem of dehydration, especially in young children. ${ }^{8}$ In Nigeria, the pharmacy is usually the first port of call in any disease condition or symptom. For this reason, it is of utmost importance for the pharmacist to be well equipped in the management of such prevalent conditions such as acute watery diarrhea in children. United Nations Children's Fund (UNICEF) and World.

Health Organization (WHO) estimate that 151,600 children die annually from diarrhea in Nigeria. ${ }^{6}$ This number of deaths can be substantially reduced if community pharmacists manage acute diarrhea in children properly.

\section{METHODS}

\section{Study Setting}

The study was done in Lagos state, south west Nigeria. It is currently the centre of commercial activities in the country. The study was carried out between January and March 2008.

Study tools: Structured self-administered questionnaire, simulated patient visits and data collection form for simulated patient visits.

Data: Questionnaire data and simulated patient visits data.

Procedure: Questionnaire was designed, pre-tested and thereafter administered to community pharmacists who gave their consent. Questionnaire was structured to collect information on the knowledge of community pharmacists in the management of acute watery diarrhea in children.

Form for simulated patient visits was designed and used for data collection by the simulated patients. The guideline for assessing the appropriateness of evaluation of patients, treatment and instruction on food and fluid intake was adopted from a booklet by World Health Organization Diarrhea Disease Control Programs - The treatment of acute diarrhea; Information for Pharmacists. ${ }^{5}$ Simulated patient visits were used to gather information on the observed practice of community pharmacists in the management of acute diarrhea in children. Eight young mothers and caregivers were trained as simulated patients for the study. The simulated patients went to community pharmacies with pharmacists on duty. They complained to the pharmacist that their child or ward had diarrhea and they needed help. That was all the information they gave to the pharmacists except when the pharmacists sought further information. They had been trained to know how to follow the interaction with the pharmacists and what answers to give for anticipated evaluation questions (Table 1 ).
The simulated patient visit scenario was designed to rule out acute bloody diarrhea (dysentery), persistent diarrhea and diarrhea with malnutrition; and to suggest acute watery diarrhea.

The simulated patients also took mental note of the questions asked by the pharmacists before making recommendation, explanation on the use of the product finally recommended, and advice or instructions on fluid intake and feeding during diarrhea (such as continue normal feeding, increase fluid intake, reduce food intake, withhold milk and any other suggestion on how to treat and manage diarrhea in children).

The simulated patients noted the recommended medicines and products, bought some of them and asked the pharmacists to indicate the most important product for the case presented. They filled in the data collection form as soon as they left the pharmacy.

\section{Sample}

A minimum sample size of 202 (at 95\% confidence interval) was determined from a population size of 428 retail community pharmacies registered with the Pharmacists Council of Nigeria. Each registered pharmacy has at least one pharmacist on duty during opening hours. Only one pharmacist filled the questionnaire in any pharmacy where there were more than one pharmacist on duty. Two hundred and six pharmacists filled the questionnaire out of the 230 who were approached $(89.6 \%$ response rate). One hundred and eighty-six simulations were done out of the 206 who filled the questionnaire (90.3\% response rate). It was ensured that the simulations were applied to the same pharmacists who filled the questionnaire in the two ways: (1) the pharmacy has just one pharmacist, and (2) the simulated patient visits were done within the same time frame as the questionnaire distributor. The lesser number of simulation indicated that some of the pharmacists who filled the questionnaires were not met on duty during the simulations. Community pharmacies in Lagos State are divided into 11 zones. About 20 pharmacies were then randomly selected from the zones to make up the sample size.

\section{Data analysis}

The data was analyzed using basic univariate analysis and chi square was used to test for significance.

\section{Ethical approval}

This study had ethical approval from the Department of Clinical Pharmacy and Bio-pharmacy of the Faculty of Pharmacy, University of Lagos. The pharmacists who participated in filling out the questionnaires gave their consent.

\begin{tabular}{|l|l|}
\hline Table 1. Simulated patient scenario & \multicolumn{1}{|c|}{ Answers } \\
\hline \multicolumn{1}{|c|}{ Anticipated evaluation questions } & Two and half years old \\
\hline Age of child & Yesterday afternoon (answer was always within 24 hours) \\
\hline Onset and duration of diarrhea & 4 times \\
\hline Frequency of stooling since onset & No \\
\hline Presence of blood and or mucus in stool & No \\
\hline Presence of fever &
\end{tabular}




\section{RESULTS}

\section{Evaluation of patients}

The questionnaire showed that $76.7 \%$ would evaluate patients using all the evaluation indicators of age of child, frequency of stooling, presence of mucus and blood in stool and pyrexia before recommending products, $14.1 \%$ would evaluate using at least three of the indicators and 9.2\% would use two or less. From the simulation, $23.1 \%$ evaluated their patients using all indicators; $19.4 \%$ used at least three indicators and $57.5 \%$ used two or less (Table 2). The difference observed was statistically significant $(p<0.05)$.

\section{Product recommendation}

Information from the questionnaire showed that $62.6 \%$ would recommend ORT as mono-therapy for acute watery diarrhea, $24.3 \%$ would recommend ORT alongside other products and $13.1 \%$ would recommend other products without ORT.

From the actual practice during simulation, $15 \%$ recommended ORT as monotherapy, $62.4 \%$ recommended ORT along with other products and $22.6 \%$ recommended other products only. The other products refer to antibiotics, antimicrobials, antidiarrheals, antispasmodics and adsorbents. The difference observed between questionnaire data and actual practice was statistically significant $(p<0.05)$

\section{Instructions on food and fluid intake during diarrhea}

Questionnaire results showed that 23.8\% knew the correct instructions to give on food and fluid intake, and $64.6 \%$ knew one correct instruction. Out of these $64.6 \%, 40.8 \%$ gave just one correct instruction while $23.8 \%$ gave one correct and one or two incorrect instructions; $10.2 \%$ gave incorrect instructions. During the simulation, $7.5 \%$ gave correct instructions of continuing feeding and increasing fluid intake to the patients. $62.9 \%$ gave one correct instruction of either continuing normal feeding or increasing fluid intake, $15 \%$ gave incorrect instruction of withholding milk and 14.5\% did not advise or instruct their patients on fluid and food intake. No pharmacist advised on reducing food intake during simulation, even though 32 pharmacists (15.5\%) had indicated in the questionnaire that they would advise reduction of food intake. The difference observed here was also statistically significant $(p<0.05)$.

\section{Other findings}

During the simulations, the pharmacists were asked to indicate the most important product out of those recommended. Out of the pharmacists who recommended ORT either as single or in combination with other products, $58.3 \%$ indicated the ORT as the most important for the treatment of acute diarrhea in children, $18.8 \%$ indicated that ORT was of equal importance as the other products that were recommended. The remaining $27.5 \%$

\begin{tabular}{|c|c|c|c|c|c|}
\hline & \multicolumn{2}{|c|}{ Questionnaire } & \multicolumn{2}{|c|}{ Simulation } & \multirow{2}{*}{$p$-value } \\
\hline & Number & Percentage & Number & Percentage & \\
\hline $\begin{array}{l}\text { Evaluation } \\
\qquad \begin{array}{r}\text { Use of all } 5 \text { evaluation indicators } \\
\text { Use of at least } 3 \text { indicators } \\
\text { Use of } 2 \text { or less indicators }\end{array}\end{array}$ & $\begin{array}{l}158 \\
29 \\
19\end{array}$ & $\begin{array}{c}76.7 \\
14.1 \\
9.2\end{array}$ & $\begin{array}{c}43 \\
36 \\
107\end{array}$ & $\begin{array}{l}23.1 \\
19.4 \\
57.5\end{array}$ & $p<0.0001$ \\
\hline $\begin{array}{r}\text { Instructions on food and fluid intake } \\
\text { Correct and complete instruction } \\
1 \text { correct instruction }+1 \text { or } 2 \text { incorrect instructions } \\
\text { Incorrect instructions } \\
\text { No instruction at all }\end{array}$ & $\begin{array}{c}49 \\
133 \\
21 \\
3\end{array}$ & $\begin{array}{c}23.8 \\
64.6 \\
10.2 \\
1.4\end{array}$ & $\begin{array}{l}14 \\
117 \\
28 \\
27\end{array}$ & $\begin{array}{r}7.5 \\
62.9 \\
15.1 \\
14.5\end{array}$ & $p<0.0001$ \\
\hline $\begin{array}{l}\text { Recommendation } \\
\text { ORT only } \\
\text { ORT + antibiotics, kaolin, metronidazole, antispasmodics } \\
\text { Antibiotics, kaolin, metronidazole, antispasmodics }\end{array}$ & $\begin{array}{l}129 \\
50 \\
27\end{array}$ & $\begin{array}{l}62.6 \\
24.3 \\
13.1\end{array}$ & $\begin{array}{c}28 \\
116 \\
42\end{array}$ & $\begin{array}{c}15 \\
62.4 \\
22.6\end{array}$ & $p<0.0001$ \\
\hline $\begin{array}{ll}\text { How often ORT is recommended } & \text { All the time } \\
\text { Sometimes }\end{array}$ & $\begin{array}{c}159 \\
38 \\
9\end{array}$ & $\begin{array}{c}77.2 \\
18.4 \\
4.4\end{array}$ & $\begin{array}{l}- \\
- \\
-\end{array}$ & $\begin{array}{l}- \\
- \\
-\end{array}$ & \\
\hline ORT as a complete management & $\begin{array}{c}81 \\
112 \\
13\end{array}$ & $\begin{array}{c}39.3 \\
54.4 \\
6.3\end{array}$ & $\begin{array}{l}- \\
- \\
-\end{array}$ & $\begin{array}{l}- \\
- \\
-\end{array}$ & \\
\hline Preparation of salt/sugar solution & $\begin{array}{c}3 \\
132 \\
71\end{array}$ & $\begin{array}{c}1.5 \\
64.1 \\
34.4\end{array}$ & $\begin{array}{l}- \\
- \\
-\end{array}$ & $\begin{array}{l}- \\
- \\
-\end{array}$ & \\
\hline $\begin{array}{r}\text { Explanation on how to use ORT sachet } \\
\text { Complete explanation } \\
\text { Incomplete explanation } \\
\text { No explanation }\end{array}$ & $\begin{array}{l}- \\
- \\
-\end{array}$ & $\begin{array}{l}- \\
- \\
-\end{array}$ & $\begin{array}{l}38 \\
56 \\
50 \\
\end{array}$ & $\begin{array}{l}26.4 \\
38.9 \\
34.7 \\
\end{array}$ & \\
\hline $\begin{array}{rr}\text { Most important product recommended } & \text { ORT } \\
\text { ORT + others (ORT of equal importance) } & \text { Kaolin } \\
\text { Metronidazole } \\
\text { Others }\end{array}$ & $\begin{array}{l}- \\
- \\
- \\
-\end{array}$ & $\begin{array}{l}- \\
- \\
- \\
-\end{array}$ & $\begin{array}{l}84 \\
27 \\
17 \\
33 \\
25\end{array}$ & $\begin{array}{l}45.2 \\
14.5 \\
19.1 \\
17.6 \\
13.5\end{array}$ & \\
\hline
\end{tabular}


indicated kaolin, metronidazole, antispasmodics and other antibiotics as the most important to be used in the case presented.

About $77 \%$ of respondents indicated that they recommend ORT all the time during cases of diarrhea while $18.4 \%$ recommend ORT occasionally. The questionnaire showed that $39.3 \%$ of pharmacists agreed to the use of ORT as a complete management for acute watery diarrhea while $54.4 \%$ disagreed. Complete explanation on the use of ORT sachets include how to mix the salt and store the solution; how long to use the solution after preparation and how and when to give the child the solution.

Thirty-eight (26.4\%) out of the 144 pharmacists who recommended ORT during the simulated visits gave the simulated patients complete explanation on the use of the sachets; 50 pharmacists (34.7\%) gave no explanation at all on how to use the product. The remaining 56 pharmacists (38.9\%) gave incomplete explanation.

\section{DISCUSSION}

The main finding of this study is that evaluation by pharmacists in actual practice for differential diagnosis of acute watery diarrhea in children was inadequate. The discrepancy between knowledge and actual practice in evaluation is consistent with earlier studies done in Thailand ${ }^{9}$, Midi-Pyrénées region $^{10}$, Pakistan $^{11}$ and other parts of Nigeria. ${ }^{12,13}$ Proper management is hinged on accurate evaluation, recommendation of ORT alone, and correct instruction on fluid and food intake. A Trinidad study of the management of acute diarrhea by community pharmacists reveals that proper management was done more in children (68.4\%) than in adults (44.1\%). ${ }^{14}$ In evaluation, $92.6 \%$ enquired about duration of diarrhea, consistency of stool, frequency of stooling and presence of mucus and blood in stool. This could have been a direct result of the distribution of a booklet published by World Health Organization titled 'Treatment of Acute Diarrhea- Information for Pharmacists' to all pharmacies in Trinidad. The booklet emphasizes the promotion of the use of oral rehydration therapy by pharmacists. ${ }^{5}$ Other countries can learn from Trinidad experience to improve management of acute diarrhea by community pharmacists.

Although $39.3 \%$ agreed to the use of ORT alone for the management of acute diarrhea, $15 \%$ did so in actual practice. A study carried out in Enugu, Nigeria, to determine the knowledge attitude and practice of ORT among private medical practitioners, shows that though they were aware of ORT, there was still a high rate of inappropriate medicine use and a deficiency in in-depth knowledge and practice of ORT. ${ }^{12}$ A similar study done in the northern part of Nigeria shows a vast difference between what pharmacists and medicine sellers claimed they did and their actual practice. The study reveals that almost all the respondents recommended medicines only, although fewer than $29 \%$ reported doing so. Sixty per cent reported recommending ORT only, while $2 \%$ were observed to do so. ${ }^{13}$ This low recommendation of ORT shows that there is still need to renew the campaign on the use of ORT amongst physicians, pharmacists, other health care professionals and the entire community. Thirty-eight pharmacists (26.4\%) explained how to prepare, store and administer the solution to the child; unlike in Trinidad where $90 \%$ gave full explanation on the preparation, storage and use of the solution. ${ }^{14}$ Explanation on preparation, storage and use of the ORT is vital to treatment success.

The behavior observed in these studies was not as a result of lack of knowledge. Many health professionals know that they should be recommending more ORT and fewer medicines for childhood diarrhea. They know the correct answer to give to an interviewer. Providing them with more information may not be enough to change their behavior as was done in Thailand. ${ }^{9}$ Interviewing and administering questionnaire appear not to be reliable ways to measure professional prescribing behavior.

Observation of actual practice or review of prescribing records is essential. ${ }^{14}$ The opposition to the use of ORT alone in the treatment of acute diarrhea in children by $54.4 \%$ of pharmacists shows disregard to the guideline stipulated by WHO. It was noted that more pharmacists $(85 \%)$ recommended antibiotics, antimicrobials, adsorbents and antispasmodics alone or in combination with ORT. The decision to treat acute diarrhea with antimicrobial therapy should be made on patient by patient basis, after investigations. For the community pharmacists, these investigations include finding out if there is blood or mucus in the stool, whether the child has fever, and the frequency and duration of the diarrhea. These investigations give a fair grasp of the child's condition to enable the pharmacists recommend appropriately. ${ }^{5}$ Even though the simulated case presented, and the result of their evaluation revealed acute diarrhea; antimicrobial agents, antibiotics, antispasmodics, and adsorbents were the mainstay of therapy. These agents have been proven ineffective in reducing fluid losses in acute diarrhea and could be dangerous in children. ${ }^{15-17}$ According to the World Health Organization, the mainstay of management of acute diarrhea in children is ORT to avoid dehydration. ${ }^{1,5}$ Sixty-two per cent of pharmacists would recommend ORT only because it is the WHO recommendation. This could have been considered fair, only if it was comparable to the actual practice. The result of this study correlates with others that have shown that ORT is grossly underused and that the claim of medicine sellers is different from their observed practice. ${ }^{6,7,12,13}$ The reluctance to recommend ORT exclusively as observed in this study could be due to the fact that the profit margin is small and pharmacists receive no incentives to sell them. This is in line with the result of the ADDR study on the reluctance of health care professionals to recommend or sell ORT ${ }^{12}$ It could also be that they do not have the confidence that ORT alone can manage acute diarrhea in children. Pharmacists' averment that ORT was of equal importance to antibiotics and antidiarrheal was inappropriate. 
During diarrhea, children lose lots of fluid resulting in their becoming weak, dehydrated and malnourished. Reduction of food intake is unnecessary as continuous feeding improves enteral nutrition by stimulating intestinal cell renewal and helps to avoid malnutrition. ${ }^{18}$ The conflicting information that was observed from questionnaire data and simulation shows that questionnaire alone may not be a reliable way to assess pharmacy practice. Simulated patient visits (i.e. observational evaluation) give a clearer picture of the actual practice. It also shows that educational intervention may not be the key to behavioral change as a good percentage of the pharmacists knew the correct answers to the questions in the questionnaire.

\section{CONCLUSIONS}

Evaluation by community pharmacists to establish acute diarrhea in children is inadequate. Fifteen percent of pharmacists recommended ORT alone for the management of acute diarrhea in children. Although the simulating patients presented a case of acute watery diarrhea of 24 hours duration, the mainstay of management was antibiotics, antimicrobials, antidiarrheal and antispasmodics. The findings in this study highlight the need for intense campaign on the management of acute watery diarrhea.

\section{CONFLICT OF INTEREST}

None declared.

Funding: This research received no specific grant from any funding agency in the public, commercial or not-for-profit sector.

\section{MANEJO DE LA DIARREA AGUDA EN NIÑOS POR LAS FARMACIAS COMUNITARIAS DE LAGOS, NIGERIA}

\section{RESUMEN}

Antecedentes: La diarrea aguda en niños lleva a la deshidratación y a la muerte si no se maneja adecuadamente. La Organización Mundial de la Salud (WHO) recomienda tratar la diarrea con terapia de rehidratación oral (ORT), fluidos y alimentos. El manejo adecuado de la diarrea esta articulado sobre una evaluación adecuada de los pacientes para identificar la diarrea aguda acuosa.

Objetivo: Comparar el conocimiento y la actitud de los farmacéuticos comunitarios con la practica observada en el manejo de la diarrea aguda en niños.

Métodos: Este estudio fue realizado utilizando dos instrumentos: cuestionario estructurado autoadministrado para evaluar el conocimiento y las actitudes de los farmacéuticos comunitarios en el manejo de la diarrea aguda en niños; $y$ visitas de pacientes simulados para evaluar la evaluación de los pacientes, la recomendación de productos y las instrucciones de ingesta de alimentos y fluidos. Se realizaron las visitas de pacientes simulados en 186 farmacias de la ciudad de Lagos, Nigeria.

Resultados: El estudio revela que el conocimiento y la actitud de los farmacéuticos comunitarios en el manejo de diarrea aguda en niños fue diferente de la práctica observada. La diferencia fue estadísticamente significativa $(\mathrm{p}<0,05)$. Durante las simulaciones, el 23\% realizaba evaluaciones correctas antes de recomendar algún producto, y el 15\% recomendaba ORT solo.

Aunque la información de los farmacéuticos indicaba una diarrea acuosa no disentérica y no colérica, se recomendaron irracionalmente antibióticos y antidiarreicos, siendo estos dos los pilares del manej de los síntomas en la práctica. Los datos de los cuestionarios revelaron que el $24 \%$ de los farmacéuticos conocía correctamente las instrucciones que debía dar sobre ingesta de fluidos y alimentos durante la diarrea, cuando solo el 8\% siguió las recomendaciones de la WHO sobre ingesta de fluidos y alimentos durante las visitas. Conclusiones: La evaluación de los pacientes para identificar la diarrea aguda fue inadecuada. La práctica observada en el manejo de la diarrea aguda en niños fue inadecuada y difirió significativamente de las respuestas en los cuestionarios. La recomendación de ORT fue escasa y el asesoramiento sobre ingesta de fluidos y alimentos fue inadecuado y en ocasiones inapropiado. Este estudio muestra que solo el $15 \%$ de los farmacéuticos comunitarios manejó la diarrea aguda de acuerdo con las recomendaciones de WHO.

Palabras clave: Diarrea; Servicios de farmacias comunitarias. Ejercicio profesional; Cumplimiento de Guías; Simulación de Pacientes; Nigeria

1. Centers for Disease Control and Prevention. The management of acute diarrhea in children: oral rehydration, maintenance, and nutritional therapy.1992. Available from: <http://www.cdc.gov/mmwr/preview/m/mwrhtml/0018677/m00018677.htm> (Accessed October 6, 2013).

2. Boschi-Pinto C, Velebit L, Shibuya K. Estimating child mortality due to diarrhea in developing countries. Bull World Health Organ. 2008;86(9):710-717.

3. College of Paediatrics, Academy of Malaysia and Malaysia Paediatric Association. Guidelines on the management of acute diarrhea in children. Available from: http://www.acamed.org.my/ (Accessed August 17, 2013).

4. World Health Organization. The Treatment of Diarrhea: A manual for physicians and other senior health workers. 4th review of document. WHO/CDD/SER/80.2. Geneva: WHO; 2005 
5. World Health Organization Diarrheal Disease Control Programme and Federation Internationale Pharmaceutique (FIP). The Treatment of Acute Diarrhea; Information for Pharmacists 1987. WHO CDD/SER/87 11

6. UNICEF/WHO. Diarrrhea-Why children are still dying and what can be done. Available from: http://www.7pointplan.org/global-childhooddiarrhea (Accessed October 8, 2013).

7. Santosham M, Keenan EM, Tulloch J, Broun D, Glass R. Oral Rehydration Therapy for diarrhea: an example of reverse transfer of technology. Pediatrics. 1997;100(5):E10. doi: 10.1542/peds.100.5.e10

8. World Health Organization. The role of the pharmacist in the health care system. WHO/PHARM/94.569 Geneve: WHO; 1994.

9. Saengcharoen W, Lerkiatbundit S. Practice and attitude regarding the management of childhood diarrhea among pharmacies in Thailand. Int J Pharm Pract. 2010;18(6):323-331. doi: 10.1111/j.2042-7174.2010.00066.x

10. Lapeyre-Mestre M, Pin M.Management of acute infantile diarrhea: A study on community pharmacy counseling in the Midi-Pyrénées region. Arch Pediatr. 2004;11(8):898-902.

11. Hussein A, Ibrahim MIM. Management of diarrhea cases by community pharmacists in 3 cities of Pakistan. East Mediterr Health J. 2012;18(6):635-640.

12. Okeke TA, Okafor HU, Amah AC, Onwuasigwe CN, Ndu AC. Knowledge, attitude, practice, and prescribing pattern of oral rehydration therapy among private practitioners in Nigeria. J Diarrhoeal Dis Res. 1996;14(1):33-36.

13. Igun U. Prescribing practices for diarrheal disease by formal and unlicensed pharmacies in Borno State Nigeria. Final report submitted to the ADDR project. 1991.

14. Karim R, Ramdahin P, Boodoo JR, Kochhar A, Pinto Pereira LM. Community pharmacists' knowledge and dispensing recommendations for the treatment of acute diarrhea in Trinidad, West Indies. Int J Clin Pract. 2004;58(3):264-267.

15. Motala C, Hill ID, Mann MD, Bowie MD. Effect of loperamide on stool output and duration of acute infectious diarrhea in infants. J Pediatr. 1990;117(3):467-471.

16. Vanderhoof JA.. Short bowel syndrome. In: Leenthal E. (ed). Textbook of gastroenterology and nutrition in infancy. 2nd edn. New York: Raven Press Ltd, 1989.

17. Pickering LK. Therapy for acute infectious diarrhea in children. J Pediatr. 1991;118(4 Pt 2):S118-S128.

18. Rehydrationproject. New formulation of oral rehydration salts ORS with reduced osmolarity. 1996-2007. Available from: http://rehydrate.org/ors/low-osmolarity-ors.htm\#reduced (Accessed October 8, 2013). 